\title{
HUBUNGAN KEMAMPUAN ANALISIS DAN MATEMATIKA DENGAN PRESTASI BELAJAR SISWA PADA MATERI LARUTAN PENYANGGA KELAS XI SMA NEGERI 4 SURAKARTA
}

\author{
Eva Nia Umi Cholifah, Sri Yamtinah ${ }^{\star}$, dan Elfi Susanti VH \\ Program Studi Pendidikan Kimia, FKIP, Universitas Sebelas Maret, Surakarta, Indonesia \\ “Keperluan korespondensi: email : jengtina_sp@yahoo.com
}

\begin{abstract}
ABSTRAK
Penelitian ini bertujuan untuk mengetahui adanya korelasi antara: (1) kemampuan analisis terhadap prestasi belajar siswa, (2) kemampuan matematika terhadap prestasi belajar siswa, dan (3) kemampuan analisis dan kemampuan matematika terhadap prestasi belajar siswa. Penelitian ini menggunakan metode korelasi. Populasi penelitian adalah siswa kelas XI SMAN 4 Surakarta. Sampel penelitian adalah kelas XI IPA 4, XI IPA 5, dan XI IPA 7 SMAN 4 Surakarta. Teknik pengambilan sampel menggunakan simple random sampling. Pengumpulan data dilaksanakan dengan instrumen tes. Analisis data menggunakan uji korelasi dan regresi linear. Hasil penelitian menunjukkan bahwa: (1) terdapat korelasi positif yang signifikan antara kemampuan analisis dengan prestasi belajar siswa dengan koefisien korelasi sebesar 0,748 dan koefisien determinasi sebesar 55,95\%, (2) terdapat korelasi positif yang signifikan antara kemampuan matematika dengan prestasi belajar siswa dengan koefisien korelasi sebesar 0,426 dan koefisien determinasi sebesar $18,15 \%$, dan (3) terdapat korelasi positif yang signifikan antara kemampuan analisis bersama-sama dengan kemampuan matematika terhadap prestasi belajar siswa dengan koefisien korelasi sebesar 0,762, persamaan regresi linear $Y=9,417+0,607 X 1+0,236 X 2$, sumbangan efektif kemampuan analisis $51,39 \%$ dan kemampuan matematika $6,61 \%$, serta sumbangan relatif kemampuan analisis $88,61 \%$ dan dan kemampuan matematika $11,39 \%$.
\end{abstract}

Kata Kunci: Korelasi, Analisis, Matematika, Prestasi Belajar

\section{PENDAHULUAN}

Pendidikan merupakan hak dan kewajiban bagi setiap anak usia sekolah di Indonesia. Salah satu kegiatan pokok pada proses pendidikan di sekolah yaitu kegiatan pembelajaran. Menurut Undang-Undang Nomor 20 tahun 2003 tentang Sistem Pendidikan Nasional, definisi pembelajaran adalah proses interaksi peserta didik dengan pendidik dan sumber belajar pada suatu lingkungan belajar. Proses pembelajaran ini diharapkan dapat berjalan dengan sebaik-baiknya untuk mencapai tujuan pendidikan nasional di Indonesia.

Salah satu kegiatan pembelajaran yang diajarkan di Sekolah Menengah Atas (SMA) yaitu pembelajaran kimia. Kimia termasuk materi yang dianggap sulit oleh siswa. Kesulitan yang dialami oleh siswa biasanya dikarenakan terdapat konsep-konsep yang harus dimengerti, adanya keterkaitan antara satu konsep dengan yang lainnya, selain itu juga banyak hitungan matematika. Berdasarkan hasil penelitian sebelumnya, diungkapkan bahwa kimia merupakan materi yang sulit hal itu karena bagian dari konteks kimia itu sendiri yang meliputi konsep kimia serta kemampuan penyelesaian masalah [1].

Pembelajaran kimia merupakan salah satu aspek penting dalam kegiatan pendidikan karena ilmu kimia banyak manfaat, aplikasi dan kaitannya dalam kehidupan baik yang disadari maupun tidak disadari, sehingga kualitas pembelajaran kimia menjadi hal yang harus terus dikembangkan dan ditingkatkan. Upaya untuk meningkatkan pembelajaran kimia harus melibatkan semua komponen yang terlibat dalam proses 
pendidikan, baik itu dari pemerintah, sekolah, guru, dan juga siswa. Salah satu upaya pemerintah yaitu peningkatan kualitas kurikulum yang diharapkan mampu membentuk kualitas pendidikan dan pembelajaran yang lebih baik lagi. Perkembangan kurikulum sekarang sampai kepada kurikulum 2013 dimana pada kurikulum ini berbeda dengan kurikulum KTSP. Guru lebih banyak berperan aktif menjadi sumber pembelajaran pada kurikulum KTSP, sedangkan pada kurikulum 2013 siswa dituntut lebih aktif dalam proses pembelajaran. Guru berperan sebagai pendamping belajar siswa serta mengontrol proses pembelajaran di kelas.

Kurikulum 2013 diharapkan mampu meningkatkan kualitas pembelajaran, salah satunya yaitu pembelajaran kimia. Salah satu tolok ukur tingkat keberhasilan proses pembelajaran yaitu hasil belajar siswa atau prestasi belajar siswa. Pembelajaran yang berhasil salah satunya dapat dilihat dari prestasi belajar siswa yang baik, namun dalam pembelajaran terkadang juga ditemukan beberapa kendala untuk mencapai prestasi belajar sesuai yang diharapkan. Prestasi belajar siswa secara umum dipengaruhi oleh beberapa faktor dan biasanya dapat digolongkan menjadi 2 faktor, yaitu faktor internal dan faktor eksternal. Beberapa contoh faktor internal yaitu kemampuan kognitif, motivasi, dan minat. Contoh faktor eksternal diantaranya kondisi perekonomian, fasilitas pembelajaran di sekolah, dan cara guru menyampaikan materi [2].

Pada suatu lingkungan atau sistem pembelajaran terdapat perbedaan karakteristik peserta didik baik dari segi kemampuan, sikap dan keterampilan, sehingga tidak semua siswa memiliki prestasi belajar sesuai yang diharapkan. Beberapa perbedaan individu yang perlu dipahami diantaranya yaitu kecerdasan, bakat, kadaan jasmaniah, penyesuaian sosial emosional, latar belakang keluarga [3]. Salah satu perbedaan yang terdapat dalam peserta didik yaitu kemampuan kognitif yang berkaitan dengan kecerdasan, diantaranya yaitu kemampuan untuk berpikir analisis serta kemampuan matematika.
Kemampuan analisis yaitu kemampuan untuk menganalisis atau membagi sesuatu ke dalam bagian-bagiannya dan dapat menjelaskan hubungan antar bagian-bagian tersebut. Setiap siswa belum tentu memiliki kemampuan analisis yang sama. Penelitian sebelumnya menyatakan semakin tinggi kemampuan analisis maka akan semakin tinggi capaian belajar kimia pada materi tabel periodik, air dan pencemarannya, kelarutan dan hasil kali kelarutan serta basa dan alkalis di Nigeria [4].

Kemampuan yang lain yang dapat mempengaruhi prestasi belajar siswa yaitu kemampuan matematika. Kemampuan matematika yaitu berkaitan dengan kemampuan numerik atau kemampuan mengolah angka serta kemampuan untuk menyelesaikan persoalan matematika. Penelitian terdahulu menyatakan bahwa ada pengaruh kemampuan matematika terhadap capaian dan sikap siswa pada materi kimia laju reaksi [5].

Materi yang dianggap sulit oleh siswa pada saat belajar kimia di kelas XI salah satunya yaitu larutan penyangga. Hal tersebut dikarenakan pada materi penyangga siswa dituntut untuk memahami konsep dan dapat menyelesaikan persamaan matematika dengan benar. Penelitian tersebut didukung dengan penelitian terdahulu yang mengungkapkan bahwa pada materi penyangga, siswa berjuang/bekerja keras untuk memahami konsep larutan penyangga serta perhitungannya karena konsep pada materi penyangga juga akan diterapkan pada materi biokimia, kimia dasar serta kimia analitik [6].

SMA Negeri 4 Surakarta merupakan SMA yang baik di kota Surakarta. Hal tersebut dibuktikan dengan nilai Ujian Nasional kimia pada tahun 2016 menempati peringkat 2 se-Surakarta dengan rata-rata 80,51. Pada proses pembelajaran di SMA Negeri 4 Surakarta juga terdapat beragam prestasi belajar kimia. Hal yang diduga berpengaruh terhadap prestasi belajar kimia tersebut yaitu kemampuan analisis dan matematika.

Berdasarkan latar belakang diatas, maka dilakukan penelitian tentang hubungan kemampuan analisis dan 
kemampuan matematika terhadap prestasi belajar siswa kelas XI SMA Negeri 4 Surakarta pada materi larutan penyangga.

\section{METODE PENELITIAN}

Penelitian ini merupakan penelitian kuantitatif dengan metode analisis mengguakan uji korelasi sederhana, korelasi berganda dan regresi linear berganda. Variabel bebas dalam penelitian ini yaitu kemampuan analisis dan matematika denangkan variabel terikat adalah prestasi belajar kimia.

Populasi penelitian yaitu siswa kelas XI SMA Negeri 4 Surakarta. Pengambilan sampel dilakukan dengan teknik simple random sampling dengan melakukan uji homogenitas terlebih dahulu terhadap populasi. Sampel penelitian yaitu kelas XI IPA 4, XI IPA 5, dan XI IPA 7.

Teknik pengumpulan data dilakukan dengan tes pilihan ganda pada kemampuan analisis, matematika, dan prestasi belajar kimia pada kelas sampel. Uji prasyarat analisis yang meliputi uji normalitas, multikolinearitas, dan linearitas dilakukan sebelum uji analisis data. Uji analisis data yang dilakukan meliputi uji korelasi pearson, korelasi ganda, dan uji regresi linear berganda.

\section{HASIL DAN PEMBAHASAN}

\section{Uji Prasyarat Analisis}

Uji prasyarat yang pertama yaitu uji normalitas yang dilakukan dengan menggunakan metode KolmogorovSmirnov. Hasil uji normalitas masingmasing variabel dapat dilihat pada Tabel 1.

Tabel 1. Hasil Uji Normalitas

\begin{tabular}{lcc}
\hline \multicolumn{1}{c}{ Variabel } & Sig. & Kesimpulan \\
\hline $\begin{array}{l}\text { Kemampuan } \\
\text { Analisis }\end{array}$ & 0,375 & Normal \\
$\begin{array}{l}\text { Kemampuan } \\
\text { Matematika }\end{array}$ & 0,058 & Normal \\
$\begin{array}{l}\text { Prestasi } \\
\text { Belajar }\end{array}$ & 0,482 & Normal \\
\hline
\end{tabular}

Berdasarkan uji normalitas pada Tabel 1, didapatkan nilai signifikansi untuk kemampuan analisis, matematika dan prestasi belajar lebih dari 0,05, hal ini berarti data berdistribusi normal.

Uji prasyarat yang kedua yaitu uji multikolinearitas dengan menggunakan nilai tolerance dan VIF. Hasil uji multikolinearitas dapat dilihat pada Tabel 2.

Tabel 2. Hasil Uji Multikolinearitas

\begin{tabular}{lcc}
\hline \multicolumn{1}{c}{ Variabel } & Tolerance & VIF \\
\hline $\begin{array}{l}\text { Kemampuan } \\
\text { Analisis }\end{array}$ & 0,845 & 1,183 \\
$\begin{array}{l}\text { Kemampuan } \\
\text { Matematika }\end{array}$ & 0,845 & 1,183 \\
\hline
\end{tabular}

Berdasarkan hasil uji multikolinearitas yang dapat dilihat pada Tabel 2, nilai tolerance pada masingmasing variabel lebih besar dari 0,1 dan nilai VIF pada masing-masing variabel lebih kecil dari 10, sehingga dapat disimpulkan tidak terdapat masalah multikolinearitas.

Uji prasyarat yang ketiga yaitu uji linearitas masing-masing variabel bebas dengan variabel terikat. Hasil uji linearitas dapat dilihat pada Tabel 3.

Tabel 3. Hasil Uji Linearitas

\begin{tabular}{lcc}
\hline \multicolumn{1}{c}{$\begin{array}{c}\text { Variabel } \\
\text { Bebas }\end{array}$} & Sig. & Kesimpulan \\
\hline $\begin{array}{l}\text { Kemampuan } \\
\text { Analisis }\end{array}$ & 0,070 & Linear \\
$\begin{array}{l}\text { Kemampuan } \\
\text { Matematika }\end{array}$ & 0,495 & Linear \\
\hline
\end{tabular}

Berdasarkan uji linearitas pada Tabel 3, nilai signifikansi kemampuan analisis dengan prestasi belajar dan kemampuan matematika dengan prestasi belajar lebih dari 0,05 , hal tersebut berarti antara variabel bebas dan terikat bersifat linier.

\section{Pengujian Hipotesis \\ a. Korelasi Sederhana}

Uji korelasi sederhana antara kemampuan analisis dengan prestasi belajar dan kemampuan matematika dengan prestasi belajar dilakukan 
dengan menggunakan korelasi Pearson. Hasil uji korelasi sederhana antara kemampuan analisis (X1) dengan prestasi belajar siswa $(\mathrm{Y})$ diperoleh nilai koefisien korelasi $(r$ ) sebesar 0,748. Nilai signifikansi menurut hasil uji yaitu sebesar 0,000. Nilai signifikansi 0,000 lebih kecil dari 0,05 , sehingga dapat disimpukan bahwa terdapat korelasi positif yang kuat yang signifikan antara kemampuan analisi terhadap prestasi belajar kimia. Korelasi positif berarti semakin tinggi kemampuan analisis sisiwa maka akan semakin tinggi prestasi belajar siswa dan sebaliknya semakin rendah kemampuan analisis siswa maka akan semakin rendah prestasi belajar siswa. Berdasarkan perhitungan didapatkan koefisien determinasi sebesar 55,95\% yang artinya kemampuan analisis memberikan kontribusi terhadap prestasi belajar sebesar $55,95 \%$ dan sisanya $44,05 \%$ ditentukan oleh variabel lain.

Penelitian ini sesuai dengan penelitian sebelumnya yang menyatakan bahwa ada korelasi positif yang kuat antara kemampuan analisis dengan capaian belajar kimia pada sekolah menengah di Nigeria [4]. Penelitian lain juga menyatakan bahwa Terdapat korelasi positif yang signifikan antara kemampuan analisis dengan prestasi belajar kimia pada materi koloid [7].

Uji korelasi sederhana antara kemampuan matematika (X2) dengan prestasi belajar (Y) diperoleh nilai koefisien korelasi $(r)$ sebesar 0,426. Nilai signifikansi menurut hasil uji yaitu sebesar 0,000. Nilai signifikansi 0,000 lebih kecil dari 0,05 , sehingga dapat disimpukan bahwa terdapat korelasi positif yang cukup kuat yang signifikan antara kemampuan matematika terhadap prestasi belajar kimia. Korelasi positif berarti semakin tinggi kemampuan matematika maka akan semakin tinggi prestasi belajar siswa dan sebaliknya semakin rendah kemampuan analisis maka akan semakin rendah prestasi belajar siswa. Berdasarkan perhitungan didapatkan koefisien determinasi sebesar $18,15 \%$ yang artinya kemampuan matematika memberikan kontribusi terhadap prestasi belajar sebesar
$18,15 \%$ dan sisanya $81,85 \%$ ditentukan oleh variabel lain.

Hasil penelitian ini terdapat kesamaan dengan penelitian sebelumnya menyatakan bahwa ada ada hubungan positif antara kemampuan matematika dengan hasil belajar fisika pada siswa kelas VII SMP Muhammadiyah Muntilan dengan korelasi kuat yaitu 0,789 [8].

\section{b. Korelasi Berganda}

Uji korelasi ganda dilakukan untuk mengetahui seberapa besar hubungan dan arah hubungan antara variabel bebas yaitu kemampuan analisis dan matematika terhadap prestasi belajar siswa.

Berdasarkan hasil uji korelasi berganda, didapatkan nilai koefisien korelasi berganda ( $R$ ) sebesar 0,762 dengan nilai signifikansi 0,00 . Nilai signifikansi yang kurang dari 0,050 menunjukkan adanya hubungan yang signifikan. Sehingga dapat disimpulkan bahwa terdapat hubungan atau korelasi positif yang kuat dan signifikan antara kemampuan analisi dan matematika terhadap prestasi belajar siswa. Korelasi positif atau korelasi searah yang berarti bahwa semakin tinggi kemampuan analisis dan matematika maka akan semakin tinggi prestasi belajar siswa dan sebaliknya semakin rendah kemampuan analisis dan matematika maka akan semakin rendah prestasi belajar siswa. Berdasarkan perhitungan didapatkan koefisien determinasi sebesar 58,06\% yang artinya kemampuan analisis dan kemampuan matematika secara bersama-sama memberikan kontribusi terhadap prestasi belajar sebesar $58,06 \%$ dan sisanya $41,94 \%$ ditentukan oleh variabel lain.

Penelitian ini memiliki hasil yang sama dengan penelitian sebelumnya yang menyatakan bahwa kemampuan memahami bacaan, kemampuan memori dan kemampuan analisis bersama-sama berkorelasi positif dan signifikan dengan prestasi belajar [7]. Penelitain lain menyatakan bahwa ada hubungan positif dan signifikan antara kemampuan numerik atau kemampuan mengolah angka dan kreativitas dengan prestasi 
belajar pada materi ikatan kimia dengan koefisien korelasi sebesar 0,550 [9]. Hal tersebut dapat menjadi pendukung penelitian ini yaitu kemampuan analisis dan matematik apabila dilakukan uji korelasi ganda dengan variabel lain terdapat hubungan positif dan signifikan.

\section{c. Regresi Linear Berganda}

Regresi linear berganda digunakan untuk menentukan persamaan regresi yang dapat memperkirakan hubungan antara variabel bebas dengan variabel terikat. Berdasarkan perhitungan didapatkan persamaan regresi sebagai berikut:

$$
Y=9,417+0,607 X 1+0,236 X 2
$$

Persamaan tersebut memiliki signifikansi 0,000 ( kurang dari 0,05) sehingga dapat disimpulkan persamaan regresi tersebut signifikan dan dapat digunakan untuk meramalkan nilai $Y$ (prestasi belajar). Dari persamaan tersebut dapat diartikan apabila nilai kemampuan analisis (X1) dan kemampuan matematika (X2) adalah 0 , maka prestasi belajar siswa nilainya sebesar 9,417 . Jika kemampuan analisis sebesar 0,607 artinya apabila kemampuan analisis naik 1 tingkatan maka prestasi belajar siswa akan mengalami kenaikan sebesar 0,607. Jika kemampuan matematika sebesar 0,236 artinya apabila kemampuan matematika naik 1 tingkatan maka prestasi belajar siswa akan mengalami kenaikan sebesar 0,236.

Pada penelitian terdahulu yang membahas tentang regresi linear ganda mendapatkan hasil $Y=5,87+0,49 X 1+$ $0,51 \mathrm{X} 2$, dimana X1 adalah kemampuan penalaran dan X2 adalah kemampuan matematika. Berdasarkan hasil tersebut kemampuan matematika juga memberikan sumbangan positif pada regresi sebesar 0,51 [8]. Hal serupa diperoleh oleh penelitian lain yang menyatakan bahwa persamaan regresi linier ganda yang diperoleh yaitu $Y=9,489+0,162 X 1$ $+0,824 X 2+0,145 X 3$. Dimana X1 adalah kemampuan memahami bacaan, $X 2$ adalah kemampuan memori dan X3 adalah kemampuan analisis. Berdasarkan hasil tersebut kemampuan analisis memberikan sumbangan positif pada persamaan regresi. [7]. Persamaan regresi kemampuan analisis memberikan sumbangan positif dengan persamaan regresi sebagai $Y=0,278 X 1+0,269 X 2$ $+41,745$ [10]. Dimana X1 adalah kemampuan memori dan $\mathrm{X} 2$ adalah kemampuan analisis. Pada penelitian ini memiliki kesamaan dengan penelitian terdahulu yaitu kemampuan analisis dan matematika memiliki koefisien regresi yang positif.

Berdaraskan persamaan regresi dapat dihitung sumbangan efektif dan relatif masing-masing variabel bebas. Sumbangan efektif merupakan sumbangan variabel secara keseluruhan termasuk variabel yang tidak diteliti. Kumlah dari sumbangan efektif yang diteliti sama dengan nilai kuadrat regresi. Sedangkan sumbangan relatif nilainya sama dengan $100 \%$. Hasil perhitungan sumbangan efektif dan relatif dapat dilihat pada Tabel 7.

Tabel 7. Hasil Perhitungan Sumbangan Efektif dan Sumbangan Relatif

\begin{tabular}{ccc}
\hline Variabel Bebas & $\mathrm{SE}(\%)$ & $\mathrm{SR}(\%)$ \\
\hline $\begin{array}{c}\text { Kemampuan } \\
\text { Analisis }\end{array}$ & 51,39 & 88,61 \\
$\begin{array}{c}\text { Kemampuan } \\
\text { Matematika }\end{array}$ & 6,61 & 11,39 \\
\hline
\end{tabular}

Nilai sumbangan efektif untuk kemampuan analisis sebesar $51,39 \%$ dan kemampuan matematika sebesar 6,61\%. Sumbangan relatif untuk kemampuan analisis sebesar $88,61 \%$ dan kemampuan matematika11,39\%. Nilai sumbangan efektif dan relatif dari kemampuan analisis lebih besar daripada kemampuan matematika pada materi larutan penyangga. Hal ini berarti kemampuan analisis lebih memberikan sumbangan terhadap prestasi belajar, hal itu dikarenakan pada materi larutan penyangga memerlukan kemampuan analisis untuk menyelesaikan suatu persoalan tentang materi larutan penyangga.

\section{KESIMPULAN}

Kesimpulan dari penelitian ini yaitu sebagai berikut: 1. Terdapat hubungan positif yang signifikan antara kemam- 
puan analisis dengan prestasi belajar siswa pada materi larutan penyangga dengan koefisien korelasi sebesar 0,748 dan koefisien determinasi sebesar $55,95 \%$, 2. Terdapat hubungan positif yang signifikan antara kemampuan analisis dengan prestasi belajar siswa pada materi larutan penyangga dengan koefisien korelasi sebesar 0,426 dan koefisien determinasi sebesar 18,15\%, dan 3.Terdapat hubungan positif yang signifikan antara kemampuan analisis bersama-sama dengan kemampuan matematika terhadap prestasi belajar siswa pada materi larutan penyangga dengan koefisien korelasi sebesar 0,762, persamaan regresi $Y=9,417+0,607 X 1$ $+0,236 \times 2$, sumbangan efektif kemampuan analisis $51,39 \%$ dan kemampuan matematika $6,61 \%$, serta sumbangan relatif kemampuan analisis $88,61 \%$ dan dan kemampuan matematika $11,39 \%$.

\section{UCAPAN TERIMA KASIH}

Terima kasih penulis ucapkan kepada keluarga besar SMA N 4 Surakarta yang telah memberikan izin untuk melakukan penelitian dan kepada dosen pembimbing yang telah memberikan bimbingan dan dukungan penulis untuk menyelesaikan penelitian ini.

\section{DAFTAR RUJUKAN}

[1] Carter, C. S., \& Brickhouse, N. W. (1989). Journal of Chemical Education, 66(3), 223.
[2] Slameto. (2013). Jakarta: Rineka Cipta.

[3] Irham, M., \& Wiyani, N. A. (2013). Jogjakarta: Ar-ruzz Media.

[4] Chijioke, U. C., \& Offiah, P. F. C. (2013). International Journal of Engineering Science Invention, 2(7), 44-57.

[5] Adesoji, F. A., \& Ibraheem, T. L. (2009). The Journal of International Social Research, 2(6), 15-25.

[6] Orgill, M., \& Sutherland, A. (2008). Chemistry Education Research and Practice, 9(2), 131.

[7] Daro'aeni, F., Yamtinah, S., \& Nurhayati, N. D. (2013). Pendidikan Kimia (JPK), 2(3), 139-145.

[8] Chusni, M. M. (2017). Berkala Fisika Indonesia, 9(1), 16-23.

[9] Cahyono, Thoriq Dwi, Masykuri, Mohammad, \& Ashadi. (2016). Jurnal Pendidikan Kimia, 5(2), 8188.

[10] Annas, A., Ashadi, \& Haryono. (2016). Jurnal Pendidikan Kimia, 5(4), 8-15. 